\title{
Animal Contact and Rabies Prophylaxis Experience: Evaluation of 625 Pediatric Cases
}

\author{
Hayvan Teması ve Kuduz Profilaksi Deneyimleri: \\ 625 Çocuk Olgunun Değerlendirilmesi
}

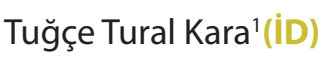 \\ ${ }^{1}$ Clinic of Pediatric Infectious Diseases, Hatay State Hospital, Hatay, Turkey
}

Cite this article as: Tural Kara T. Animal contact and rabies prophylaxis experience: Evaluation of 625 pediatric cases. J Pediatr Inf 2020;14(1):e15-e20.

Abstract

Objective: Rabies is a zoonotic disease that infects mammals and can be fatal. Many people in the world are bitten by rabies suspected animals. However, it is possible to prevent the disease by vaccination of animals and pre- and post-exposure prophylaxis measures. The aim of this study was to evaluate the clinical and demographic characteristics of pediatric patients admitted to our hospital for rabies suspected contact.

Material and Methods: Patients aged 0-18 years who were admitted to our hospital between January 1 and December 31, 2018 due to contact with animals at risk of rabies such as licking, scratching or biting were included into the study. Demographic and clinical data of the patients were obtained retrospectively. SPSS 22.0 program was used for statistical analysis of the data.

Results: Of the 625 children included into the study, $64.5 \%$ were males. Mean age of the patients was $8.9 \pm 5.1(9 ; 0-18)$ years. When the patients were classified according to age groups, the highest number of children was between 12-18 years (34.1\%). Most of the patients (60.2\%) were living in urban areas. The most frequent contact was with cats (57.4\%). Often, bite/scratching occurred from a single site. Most of these were contacted from the hand region (26.7\%). Prior to admission, $71.4 \%$ of the patients had undergone wound care. Intramuscular rabies immunoglobulin (40 IU/kg) was administered to $113(18.1 \%)$ patients admitted to hospital at the appropriate time. In post-exposure period, 145 (23.2\%) animals could be observed for at least 10 days. After rabies vaccination, fever occurred in $1.1 \%$ of the patients within the first 24 hours. There were no other local or systemic complications related to the vaccine. Oral antibiotic prophylaxis was given to $8.3 \%$ of the patients. In addition $1.4 \%$ of the patients received parenteral antibiotic treatment for severe
Öz

Giriş: Kuduz, memelileri enfekte eden ve ölümcül olabilen zoonotik bir hastalıktır. Tüm dünyada çok sayıda insan kuduz riskine sahip hayvanlar tarafından ısırılmaktadır. Ancak hayvanların aşılanması, temas öncesi ve temas sonrası profilaksi önlemleri ile hastalıktan korunmak mümkün olmaktadır. Bu çalışmada, kuduz şüpheli teması nedeniyle hastanemize başvurmuş çocuk hastaların klinik ve demografik özelliklerinin değerlendirilmesi amaçlanmıştır.

Gereç ve Yöntemler: Çalışmaya, 1 Ocak 2018-31 Aralık 2018 tarihleri arasında kuduz riski olan hayvanlarla yalanma, tırmalanma veya ısırılma gibi temasları nedeniyle hastanemize başvurmuş 0-18 yaş arası çocuk hastalar dahil edildi. Hastalara ait demografik ve klinik bilgiler geriye dönük olarak elde edildi. Verilerin istatistiksel analizinde SPSS 22.0 programı kullanıldı.

Bulgular: Çalışmaya dahil edilen toplam 625 çocuk hastanın \%64.5'i erkekti. Hastaların yaş ortalaması $8.9 \pm 5.1$ (9; 0-18) yıldı. Hastalar yaş gruplarına göre sınıflandırıldığında en çok 12-18 yaş grubu (\%34.1) çocuklar bulunmaktaydı. Hastaların çoğunluğu (\%60.2) kentsel bölgede yaşamaktaydı. En sık kedilerle (\%57.4) temas olmuştur. Çoğunlukla tek bölgeden ısııılma/tırmalanma gerçekleşmiştir. Bunların içinde en çok el bölgesinden (\%26.7) temas olmuştur. Başvurudan önce \%71.4 hastaya yara bakımı yapılmıştır. Uygun zamanda hastaneye başvuran 113 (\%18.1) hastaya intramusküler kuduz immünglobulini (40 IU/kg) uygulanmıştır. Temas sonrası dönemde 145 (\%23.2) hayvan en az 10 gün süreyle gözlenebilmiştir. Kuduz aşısı uygulaması sonrası ilk 24 saat içinde \%1.1 hastada ateş gelişmiştir. Bunun dışında aşıya bağlı herhangi bir lokal ya da sistemik komplikasyon görülmemiştir. Hastaların \%8.3'üne oral

Correspondence Address/Yazışma Adresi

Tuğçe Tural Kara

Hatay Devlet Hastanesi,

Çocuk Enfeksiyon Hastalıkları Kliniği,

Hatay-Türkiye

E-mail: tugcetural@hotmail.com 
wound infection. None of the patients developed signs and symptoms of rabies during the study period.

Conclusion: Although rabies suspected contact constitutes an important public health problem in our region, our study supports that it is possible to obtain low morbidity and mortality rates with the prophylaxis practices recommended in the guidelines for patients in contact with risky animals. In addition to proper prophylaxis, vaccination of animals is important for disease control.

Keywords: Contact, prophylaxis; protection, rabies, rabies vaccine

\section{Introduction}

Rabies, whose agent is a virus belonging to the Lyssavirus species of the Rhabdoviridae family, is a zoonotic disease infecting mammals and causing fatal encephalitis (1). A large number of people are bitten by rabies suspected animals every year all around the world. The virus is most often acquired by the infected animal's bite when the wound is exposed to the animal's saliva. In addition, being scratched by the animal and contamination of the mucosae with infected fluids carry a risk (2). More than $90 \%$ of the cases in developing countries are caused by dogs. In our country, data of the last 20 years have demonstrated that $90.7 \%$ of the animals infected with rabies are domestic pets, and dogs (43.6\%) have ranked the highest among all (3).

Rabies remains to be an important health problem in many parts of the world. The disease is one of the most feared infectious diseases with high mortality rates generated by an acute progressive encephalitis picture. Although Louis Pasteur developed the first rabies vaccination in the year 1885 , it is estimated according to the data of the World Health Organization (WHO) that 60.000 people die of rabies every year worldwide (4). Most of the mortalities occur in developing countries where rabies control is inadequate and insufficient. Limited access to rabies vaccination and specific immunoglobulins constitutes a crucial problem (5). Moreover, $80 \%$ of the mortalities involve those living in the countryside, and $40 \%$ of the patients are under the age of 15 . Our country is endemic in terms of rabies. A total of 250.000 rabies suspected contact is reported in a year, and an average of 1-2 rabies cases are seen (3).

Rabies is an acute progressive disease that becomes $100 \%$ fatal once clinical findings arise. However, it is possible to prevent the disease by vaccination of animals and pre- and post-exposure prophylaxis measures. Therefore, pre-exposure prophylaxis is recommended for individuals at a high risk for rabies suspected animal contact, and post-exposure prophylaxis is recommended as soon as possible for all individuals who got in contact with rabies suspected animals. These recommendations include local wound care, rabies vaccination and rabies immunoglobulin according to its risk category (3).

The aim of this study was to retrospectively evaluate our prophylaxis experience and demographic characteristics of antibiyotik profilaksisi verilmiştir. Ayrıca \%1.4 hasta ciddi yara yeri enfeksiyonu nedeniyle parenteral antibiyotik tedavisi almıştır. Çalışma süresi boyunca hiçbir hastada kuduz hastalığı belirti ve bulguları gelişmemiştir.

Sonuç: Bölgemizde kuduz riskli teması önemli bir halk sağlık sorunu teşkil etmesine rağmen, çalışmamız şüpheli hayvan ile temas eden hastalara rehberlerde önerilen profilaksi uygulamaları ile düşük morbidite ve mortalite oranları elde etmenin mümkün olacağını desteklemektedir. Uygun profilaksi uygulamaları yanında hayvanların aşılanması hastalığın kontrolü için önem teşkil etmektedir.

Anahtar Kelimeler: Kuduz, kuduz aşısı, korunma, profilaksi, temas

pediatric patients admitted to our hospital for rabies suspected contact.

\section{Materials and Methods}

Patients included into the study were those aged 0-18 years who presented to the Pediatric Infectious Diseases Clinic of our hospitals between January 1 and December 31, 2018 with history of rabies suspected contact and received diagnoses according to HIS 2013 (ICHD-III) criteria, which included Z24.2, the need to be vaccinated against rabies, W54, being bitten or wounded by dog, and Z20.3, rabies contact and exposure. Demographic and clinical data of the patients were obtained from patient charts and rabies suspected contact registration book of our hospital. Data regarding patient age, sex, region of inhabitance, wound site, time elapsed from contact to presentation to hospital, clothing status, way of contact, wound care before presentation, kind of animal in contact, whether the animal had an owner or nor, vaccination status of the animal, supervision status of the animal, risk category according to Rabies Field Guideline, the applied prophylaxis, prior rabies vaccination status of the patient, whether or not any complications occurred after the bite, and any unwanted side effects after vaccination of $\mathrm{Ig}$ were recorded.

Evaluation of the patients, determination of the risk category, prophylaxis status and follow-up were all carried out in accordance with the Rabies Field Guideline of the Ministry of Health (6). The categories are as follows: category 1- touching or feeding the animal and licking of intact skin; category 2-mild laceration of the skin (no subcutaneous injuries), scratches or injury with no bleeding; category 3-one or more bites and scratches that injure the skin, contact of the open skin wounds and mucosae with animal saliva, lesions on the head, neck and fingertips where there are extensive nerve endings; and category 5 -high risk contact with wild animal species with a possibility to have rabies. Patients whose skin integrity had been destroyed received local wound care. In addition, rabies vaccination, rabies Ig (the dose for human-acquired rabies: 20 IU/ $\mathrm{kg}$, animal-acquired rabies: $40 \mathrm{lU} / \mathrm{kg}$ ), tetanus vaccination and antibiotic prophylaxis were all started in accordance with the recommendations of "Rabies Field Guideline" (6).

SPSS 22.0 program was used for the statistical analysis of the data obtained. Parametric data and categoric variables 
were expressed respectively as mean \pm standard deviation and percentage. The study was approved by the Clinical Studies Ethics Committee of Mustafa Kemal University Medical Faculty (07.03.2019). Necessary approval was received from the Provincial Directorate of Health in 03.05.2019.

\section{Results}

A total of 625 pediatric patients admitted to our hospital for rabies suspected contact were included into the study. Four hundred and three (64.5\%) patients were males. Median age of the patients was $8.9 \pm 5.1(9 ; 0-18)$ years. When the patients were grouped as regards age, there were 210 children in the $0-5$ age group (33.6\%), 202 children in the 6-11 age group (32.3\%) and 213 children in the $12-18$ age group (34.1\%). Of the $60.2 \%$ patients resided in the urban region. The patients mostly presented in the months of July ( $n=110,17.6 \%)$ and $(n=108,17.3 \%)$.

The most frequent risky contact was seen to be found in cats in our study. When animal kinds were compared with regard to patient age, there was $80.5 \%(n=169)$ cat and $19.5 \%(n=41)$ dog contact in the $0-5$ age group; $47.5 \%(n=96)$ cat and $51.5 \%(n=$ 104) dog contact in the 6-11 age group, $0.5 \%(n=1)$ monkey and $0.5 \%(n=1)$ horse contact, and $44.1 \%(n=94)$ cat and $55.9 \%(n=$ 119) dog contact in the 12-18 age group. Figure 1 shows contact with animal kind according to age groups of the patients.

Majority of the patients were exposed to single region biting and/or scratching. More than one region was affected in a total of 57 (9.1\%) patients. Most contact took place in hands (26.7\%) when contact regions were classified. Following hands, upper extremity, lower extremity and the truncus were respectively affected. No bite was detected on the genital region in any patients. Moreover, no sign or symptom was determined in the patients suggestive of internal organ, bone or joint involvement. A total of 328 patients (52.5\%) were bitten over clothing.

Of the $71.4 \%$ patients $(n=446)$ had received wound care prior to admission. Nearly all patients (97.8\%) presented to hospital within the first 12 hours of contact. The remaining 7 (1.1\%) patients applied to hospital within 12-24 hours, $2(0.3 \%)$ within 24-48 hours, $4(0.6 \%)$ within $2-5$ days, and $1(0.2 \%)$ patient on the $7^{\text {th }}$ day. Late admission of the patients to hospital was a result of transportation difficulties and lack of knowledge on the rabies disease. $65.1 \%, 22.1 \%$ and $12.8 \%$ of the patients presented with having been scratched, bitten and both, respectively. Of the $77.1 \%$ animals that got into contact were estray, $20.3 \%$ had owners but were not vaccinated, and $2.6 \%$ had owners and were vaccinated. $480(76.8 \%)$ animals could not be kept under observation post-contact, but 145 (23.2\%) animals could be observed for at least 10 days. Rabies symptoms did not develop in the animals observed, and the planned vaccination applications of the children who got into contact with these animals were terminated at the end of the observation period.

When the patients were divided into categories according to Rabies Field Guideline, $2.7 \%(n=7)$ of the patients were category $1,67 \%(n=419)$ were category 2 and $30.3 \%(n=189)$ were category 3. Intramuscular rabies immunoglobulin $(40 \mathrm{lU} / \mathrm{kg})$ was injected to 113 patients (18.1\%) who applied to hospital on time. Five category 3 patients re-applied to hospital due to the fact that the animal escaped during the observation peri-

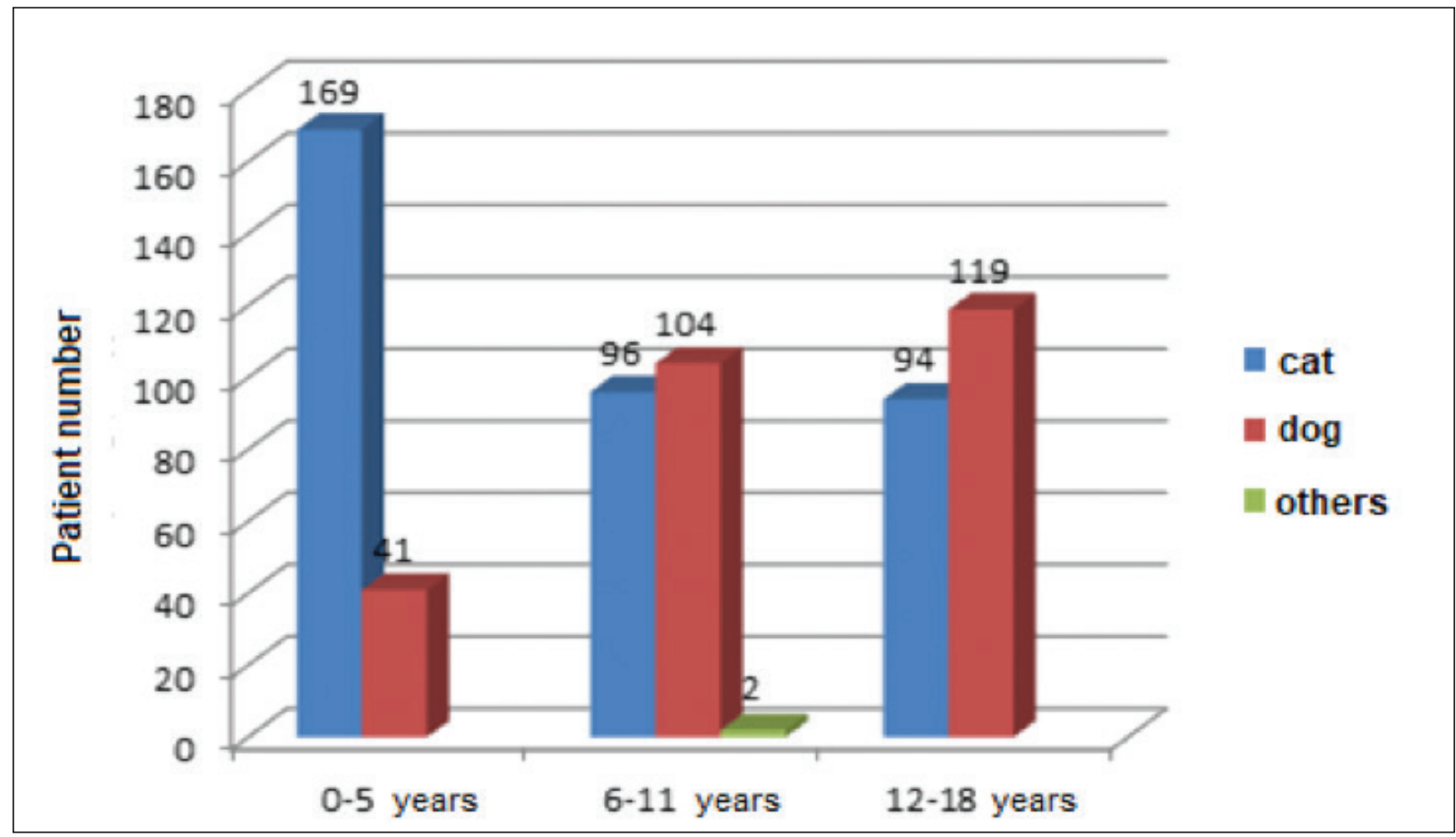

Figure 1. Kinds of animals that patients were in contact with according to age groups 
Table 1. Demographics of children with rabies suspected contact

\begin{tabular}{|l|c|}
\hline Total patient number & 625 \\
\hline Mean age \pm SD (years) & $8.9 \pm 5.1$ \\
\hline Sex (male) & $403(64.5 \%)$ \\
\hline Age & \\
0-5 years & $210(33.6 \%)$ \\
6-11 years & $202(32.3 \%)$ \\
12-18 years & $213(34.1 \%)$ \\
\hline Duration of application & $611(97.8 \%)$ \\
< 12 hour & $7(1.1 \%)$ \\
12-24 hour & $2(0.3 \%)$ \\
24-48 hour & $4(0.6 \%)$ \\
2-5 day & $1(0.2 \%)$ \\
\hline$>5$ day & $297(47.5 \%)$ \\
\hline Clothing & $328(52.5 \%)$ \\
None & \\
Over the clothing & \\
\hline Place of living & $376(60.2 \%)$ \\
City & \\
\hline Kind of animal & $359(57.4 \%)$ \\
Cat & $264(42.2 \%)$ \\
Dog & $1(0.2 \%)$ \\
Monkey & $127(20.2 \%)$ \\
Horse & $446(71.4 \%)$ \\
\hline Wound care & \\
\hline Contact type & $1387(65.12 .1 \%)$ \\
Scratching & $480(76.8 \%)$ \\
Biting & \\
Scratching and biting & \\
\hline Status of the animal's observation & \\
Yes & \\
No & \\
\hline Animal's vaccination status & \\
With owner, vaccinated & \\
Estray & \\
\hline & \\
\hline
\end{tabular}

Table 2. Contact regions in pediatric patients with rabies suspected contact

\begin{tabular}{|l|l|}
\hline Contact region & n (\%) \\
\hline Hand & $182(26.7)$ \\
\hline Upper extremity & $161(23.6)$ \\
\hline Lower extremity & $129(18.9)$ \\
\hline Truncus & $88(12.9)$ \\
\hline Unknown & $67(9.8)$ \\
\hline Gluteal region & $32(4.7)$ \\
\hline Head-neck & $23(3.4)$ \\
\hline & \\
\hline
\end{tabular}

od, and two category 3 patients re-applied due to the death of the animal. Ig was not administered to these patients since 7 days had passes following the first dosage of the vaccination; however, vaccination was completed to five doses. Ten (1.6\%) patients were exact dose vaccinated owing to prior contact. A total of two doses of rabies vaccination were given to these patients on days 0 and 3 . There were delays in vaccination in 2 $(0.3 \%)$ patients after the first dosage and in $13(2.1 \%)$ patients after the second dosage among those that were included in rabies prophylaxis. These families were contacted by the Provincial Directorate of Health and vaccination was stopped in cases the animal could be watched for 10 days. Vaccination was continued in other cases. Seven (1.1\%) patients developed fever in the first 24 hours of rabies vaccination. Fever was not observed in the following vaccinations on follow-up. Local or systemic side effects were not seen in the patients.

Of the $8.3 \%(n=52)$ patients received antibiotic prophylaxis. Oral amoxicillin clavulanate was prescribed to 28 (53.8\%) patients, and oral cephalosporin was prescribed to 15 (28.8\%). Antibiotic prophylaxis was given due to being bitten on the face $(\mathrm{n}=$ $15)$, being bitten on the hand $(n=32)$, closure needing wound $(n=2)$, patients that presented in the first eight hours with edema and contusion $(n=3)$. Nine $(17.3 \%)$ patients received parenteral antibiotic treatment (sulbactam-ampicillin $150 \mathrm{mg} / \mathrm{kg} /$ day) for severe wound site infection. No complication like abscess, osteomyelitis or necrotizing fasciitis was seen during follow-up. No patient developed rabies during the study period. Demographics of the patients are summarized in Table 1.

\section{Discussion}

In this study, 625 pediatric patients admitted to our hospital for rabies suspected contact were examined. Similar to the literature, it was seen in our study that male children were more affected (7-9), which can be connected to the fact that male children are more outdoors, have more contact with animals, and thus, are at more risk of being bitten and/ or scratched by them. Median age of the patients was $8.9 \pm$ 5.1 years, and most frequent age group was the 12-18 age group. From our country, Kara et al. have reported the mean age of children presenting with rabies suspected contact as 9.3 years and emphasized that those affected more were between 11 and 16 years of age. The authors have indicated that the reason for frequent contact in this age group was due to the fact that they were outdoors playing or doing sports (11). In a study by Samanta et al. reviewing 308 pediatric patients with rabies suspected contact, male children were nearly twice in number compared to females and children over the age of 5 were detected most frequently among all. This difference was associated with the fact that boys were more interested in outdoor activities compared to girls (12).

In a study by Krzowska-Firych et al. comprising 519 pediatric patients, a larger number of patients applied from urban regions similar to our study (13). However, in the literature, contacts have been reported to be more vastly seen in the countryside (5). We are of the opinion that this situation is a result of the 
growing number of dogs on streets in cities, and hence, animal control is harder and, in the countryside, public awareness is low and there is not sufficient number of cases that apply to hospital after animal contact. Kurt et al. have also reported that those that apply to hospitals are from cities $(70.3 \%)$, which has been associated with lack of awareness of the people living in the countryside regarding rabies vaccination centers and with the insufficiency of public transportation system (14).

Yizengaw et al. have reported that hospital admissions were made most frequently in spring and summer time. The authors have claimed that this situation was due to the breeding season of dogs (15). In our study, following summer (June, July) with the highest rate of admissions, spring was found the second highest. We are of the opinion this is a result of children being more outdoors than other seasons. However, Ren et al. have reported human rabies cases more in the fall and summer seasons. Agricultural activities in these months have been found a risk factor for the animal attacks (16).

While wild animals are more responsible in rabies transmission to humans in developed countries, domestic pets are commonly responsible for the transmission in developing countries like Turkey. Of these, dogs are the main source of mortality due to rabies in humans and are responsible for 99\% of the transmission (17). Dogs have been most frequently identified as animal contact in studies including pediatric patients performed in our country $(10,18)$. Yet, contact with cats was found more frequently in our study. We believe that the reason for us to have obtained different results from those of the literature is due to the large number of patients found in the $0-5$ age group and their contact with cats (80.5\%).

Of the $77 \%$ animals that got into contact with the children in our study were estray. Only $11.2 \%(n=16)$ of the animals with owners were vaccinated, which shows us that animal owners are not adequately aware of the severity of the disease. Animal vaccination is crucial in a fatal disease like rabies. Therefore, animal control in regions and locations with a large number of stray animals should be carried out, and public awareness should be raised for animal vaccination. We are of the opinion that there will be a decrease in the number of pediatric patients applying to hospital and prevent the financial and workforce loss the country faces with adequate awareness and measures taken.

Contact region in pediatric cases changes with the age of the patient and kind of the animal. Dog bites in preschool children are generally seen in the head and neck regions probably because the head and neck regions of these children are at the level of the animal's mouth (19). Extremity injuries become more common as the child grows. Cat bites are mostly seen in extremities $(20,21)$. Samanta et al. have reported that the face and truncus are more in contact in young children (especially under the age of five) and right lower leg and left lower leg are the commonly affected regions in older children. The authors have also indicated that older children tend to agitate animals and have more bite marks on their extremities in order to defend themselves (12). Since cat contact was found more commonly in our study, hands and upper extremity were detected as frequent contact regions. Moreover, the general use of hands and feet by children to pet cats and dogs may have caused this result.

It is aimed by animal contact management to care for the wound as soon as possible, determine infection or other severe complication risks, application of necessary antimicrobial and active/passive prophylaxis, and thus minimize the risk of complication development (19). Washing the wound with soap and water or with povidone iodide solution, if any, is most effective in diminishing rabies transmission (22). Of the $71.4 \%$ patients in our study had performed wound care before applying to our hospital. Furthermore, majority of the patients (97.8\%) applied to our hospital within the first 12 hours and received necessary prophylactic measures. We believe that the nondevelopment of severe complications is due to pre-admission wound care and early application to hospital.

There is limited data in the literature on antibiotic prophylaxis aimed at animal bites. Infectious Diseases Society of America (IDSA) guidelines recommend the use of antimicrobial agents preventive of soft tissue and skin infections in immunosuppressed, asplenic patients and in those with advanced liver disease and in mild to severe injuries, particularly bone, tendon or joint capsule injuries and face, hand, foot or genital organ injuries. Amoxicillin clavulanate has been recommended as the first option due to its aerobe and anaerobe efficiency. Duration of preemptive treatment has been recommended as 3-5 days; however, all children with bite injuries have been recommended to be re-evaluated within 24-48 hours in order to observe infection signs and symptoms. It has been emphasized that the duration of treatment should be planned according to the region and severity of the wound and to the clinical response of the patient (23). It has been reported in the literature that lower infection rates are seen with amoxicillin clavulanate prophylaxis applied for animal bites at various skin thicknesses in patients applying to hospital 9 hours after being bitten (24). In our study, antibiotic prophylaxis was given to $8.3 \%(n=52)$ of the patients. No complication was developed in any patients with appropriate dosage and length of prophylaxis.

In conclusion, rabies remains a public health problem in developing countries like ours. The fact that most of the animals that got in contact with the patients were estray showed that public awareness towards rabies should be raised and pre and post contact prophylactic measures be taken. Low rates of vaccination among the animals with owners also constituted a risk. Therefore, it is necessary to inform pet owners of the disease, to encourage them to get their pets vaccinat- 
ed and to make veterinary monitoring mandatory, if necessary. Two thirds of the children comprised of school-aged children older than five years of age. Hence, informing children at school about rabies may be helpful in avoiding contact. Early application reduces the prevalence of the disease and its complications. Informing both individuals and healthcare personnel regarding this fatal disease and raising public awareness with policies supported by healthcare authorities are of grave importance in the management of the disease.

Ethics Committe Approval: The study was approved by the Clinical Studies Ethics Committee of Mustafa Kemal University Medical Faculty (07.03.2019).

Informed Consent: None due to the retrospective nature of the study.

Peer-review: Externally peer-reviewed.

Author Contributions: Concept - TTK; Design - TTK; Supervision TTK; Materials - TTK; Data Collection and/or Processing - TTK; Analysis and/or Interpretation - TTK; Literature Review - TTK; Writing - TTK; Critical Review - TTK.

Conflict of Interest: No conflict of interest was declared by the authors.

Financial Disclosure: The authors declared that this study has received no financial support.

\section{References}

1. Hemachudha T, Ugolini G, Wacharapluesadee S, Sungkarat W, Shuangshoti S, Laothamatas J. Human rabies: neuropathogenesis, diagnosis, and management. The Lancet Neurology 2013;12:498-513. "[C Cross Ref $]_{1}^{\prime \prime}$

2. Hwang GS, Rizk E, Bui LN, Iso T, Sartain El, Tran AT, et al. Adherence to guideline recommendations for human rabies immune globulin patient selection, dosing, timing, and anatomical site of administration in rabies postexposure prophylaxis. Hum Vaccin Immunother 2020;16(1):51-60. '[C Cross Réf $]_{1}^{1}$

3. T.C. Sağlık Bakanlığı Kuduz Profilaksi Rehberi, 2019. https://dosyamerkez.saglik.gov.tr/Eklenti/30025,kuduz-profilaksi-rehberipdf.

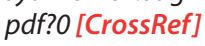

4. The World Health Organization. Rabies. Epidemiology and burden of disease. http://www.who.int/rabies/epidemiology/en/ (Accessed on September 26, 2018). [CrossRef].

5. De Nardo P, Gentilotti E, Vairo F, Nguhuni B, Chaula Z, Nicastri E, et al. A retrospective evaluation of bites at risk of rabies transmission across 7 years: The need to improve surveillance and reporting systems for rabies elimination. PLoS One 2018;13:0197996. "[C Cross Ref $]_{1}$

6. T.C. Sağlık Bakanlığı Kuduz Profilaksi Rehberi, 2014. https://dosyaism. saglik.gov.tr/Eklenti/21615,kuduz-saha-rehberipdf.pdf? [' [Cross Ref $]_{1}$

7. Salomão C, Nacima A, Cuamba L, Gujral L, Amiel O, Baltazar C, et al. Epidemiology, clinical features and risk factors for human rabies and animal bites during an outbreak of rabies in Maputo and Matola cities, Mozambique, 2014: Implications for public health interventions for ra-

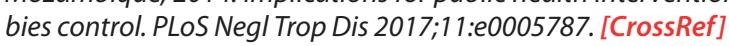

8. Punguyire DT, Osei-Tutu A, Aleser EV, Letsa T. Level and pattern of human rabies and dog bites in Techiman Municipality in the Middle Belt of Ghana: a six year retrospective records review. Pan Afr Med J 2017;28:281. [C [rossRefi]"

9. Uzunovic S, Skomorac M, Basic F, Mijac-Music I. Epidemiological features of human cases after bites/scratches from rabies-suspected animals in Zenica-Doboj Canton, Bosnia and Herzegovina. J Prev Med Public Health 2019;52:170-8. "[C Cross Reff $]_{1}$

10. Kara SS, Delice O. Hayvan ısırığı ve kuduz riskli teması olan çocuk hastaların değerlendirilmesi. Kafkas J Med Sci 2018;8:13-9. "[C Cross Refef]"

11. Aydın E, Yılmaz Y, Aydın S, Özlece H, Kadanalı A, Akıncı E, et al. Ikinci basamak sağlık kurumuna müracaat eden kuduz şüpheli temas vakalarının değerlendirilmesi. Kafkas J Med Sci 2016;6:98-101. "[C C

12. Samanta M, Mondal R, Shah A, Hazra A, Ray S, Dhar G, et al. Animal bites and rabies prophylaxis in rural children: Indian perspective. J Trop Pediatr 2016;62:55-62. [CrossRef]

13. Krzowska-Firych J, Mazurek E, Hasiec B, Tomasiewicz K. The first report evaluating the post-exposure rabies prophylaxis in children exposed to animals in the Lublin Province (Eastern Poland) in 2010-2016 - a retrospective study. Hum Vaccin Immunother 2018;14:2660-5. "[Cross Reef $]_{1}^{\prime}$

14. Kurt N, Demir A, Araç S, Araç E, Dursun R. Five year analysis of rabies suspected animal contact cases which is a significant public health problem in the Southeast Anatolia Region. IAMR 2017;9:1-5. [CrossRef]

15. Yizengaw E, Getahun T, Mulu W, Ashagrie M, Abdela I, Geta M. Incidence of human rabies virus exposure in northwestern Amhara, Ethiopia. BMC Infect Dis 2018;18:597. [C Cross Ref $]_{1}$

16. Ren J, Gong Z, Chen E, Lin J, Lv H, Wang W, et al. Human rabies in Zhejiang Province, China. Int J Infect Dis 2015;38:77-82. "[C Cross Ref $]_{1}$

17. Yin $C P$, Zhou H, Wu H, Tao XY, Rayner S, Wang SM, et al. Analysis on factors related to rabies epidemic in China from 2007-2011. Virol Sin 2012;27:132-43. [C Cross Ref]

18. Derinöz $O$, Akar T. Bir üniversite hastanesi çocuk acil servisine başvuran hayvan Isırıkları olguları. J Pediatr Emerg Intensive Care Med 2017;4:22-6. [CrossRef]

19. Bula-Rudas FJ, Olcott JL. Human and animal bites. Pediatr Rev 2018;39:490-500. "[C CrossRef $]_{1}$

20. Patronek GJ, Slavinski SA. Animal bites. J Am Vet Med Assoc 2009;234:336-45. [CrossRef]

21. Ellis R, Ellis C. Dog and cat bites. Am Fam Physician 2014;90:239-43. [CrossRef]

22. Grill AK. Approach to management of suspected rabies exposures: what primary care physicians need to know. Can Fam Physician 2009;55:24751. [CrossRef]

23. Stevens DL, Bisno AL, Chambers HF, Dellinger EP, Goldstein EJ, Gorbach $S L$, et al. Practice guidelines for the diagnosis and management of skin and soft tissue infections: 2014 update by the Infectious Diseases Society of America. Clin Infect Dis 2014;59:147-59. "[Cross Ref ']

24. Brakenbury PH, Muwanga C. A comparative double blind study of amoxycillin/clavulanate vs. placebo in the prevention of infection after animal bites. Arch Emerg Med 1989;6:251-6. "[CrossRefi]" 